\title{
EFEKTIVITAS IMPLEMENTASI KEBIJAKAN PERATURAN WALIKOTA YOGYAKARTA NOMOR 79 TAHUN 2010 TENTANG PEMBATASAN USAHA WARALABA MINIMARKET DI KOTA YOGYAKARTA
}

\author{
Nurindah Mahareta ${ }^{1}$, Muhammad Fatchur Rozi ${ }^{2}$ \\ Magister Ilmu Hukum Universitas Airlangga \\ Kampus B, Jalan Dharmawangsa Dalam Selatan, Surabaya, Jawa Timur \\ nurindahmahareta@yahoo.com
}

\begin{abstract}
Abstrak
Penelitian ini bertujuan untuk mengetahui efektivitas penerapan kebijakan Peraturan Walikota nomor 79 Tahun 2010 dalam upaya melindungi keberadaan pasar tradisional di Kota Yogyakarta. Penelitian ini adalah berjenis kualitatif dengan pendekatan deskriptif. Teknik pengumpulan data dilakukan dengan wawancara, observasi, dan dokumentasi. Teknik pengambilan sampel adalah dengan cara purposive sampling. Informan dalam penelitian ini adalah para pedagang di pasar tradisional yang tersebar di Kota Yogyakarta dan staf Dinas Perindustrian dan Perdagangan Kota Yogyakarta.

Berdasarkan hasil penelitian dapat diketahui bahwa kebijakan Peraturan Walikota Yogyakarta nomor 79 Tahun 2010 belum diketahui oleh seluruh pedagang di pasar tradisional yang berada di wilayah Kota Yogyakarta. Kebijakan Peraturan ini dinilai efektif dalam memberikan perlindungan terhadap keberadaan pasar tradsional di wilayah Kota Yogyakarta. dan didukung pelaksanannya oleh sebagian besar pedagang di pasar Tradisional di wilayah Kota Yogyakarta. Namun demikian, harus diterapkan di seluruh wilayah Kota Yogyakarta agar melindungi pedagang dengan usaha kecil. Peraturan ini tidak perlu direvisi.
\end{abstract}

Kata Kunci: Efektivitas, Kebijakan, Pasar Tradisional

\begin{abstract}
This study aims to determine the effectiveness of the implementation of Mayor Regulation number 79 of 2010 in an effort to protect the existence of traditional markets in the city of Yogyakarta. This research is a qualitative type with a descriptive approach. Data collection techniques carried out by interview, observation, and documentation. The sampling technique is by purposive sampling. The informants in this study were traders in traditional markets scattered in the city of Yogyakarta and staff of the Yogyakarta City Industry and Trade Office.

Based on the results of the study it can be seen that the policy of Yogyakarta Mayor Regulation number 79 of 2010 is not yet known by all traders in traditional markets in the Yogyakarta City area. This Regulation Policy is considered effective in providing protection against the existence of traditional markets in the City of Yogyakartasupported by the implementation of most traders in traditional markets in the city of Yogyakarta. However, it must be applied in all areas of the City of Yogyakarta in order to protect traders with small businesses. This regulation does not need to be revised.
\end{abstract}

Key words: Effectiveness, Policy, Traditional Markets

\footnotetext{
${ }_{1}^{1}$ Mahasiswa Master Ilmu Hukum Universitas Airlangga

${ }^{2}$ Mahasiswa Master Ilmu Hukum Universitas Airlangga, muhammadfatchurozi14@gmail.com
} 


\section{A. Pendahuluan}

Era globalisasi sekarang ini terjadi fenomena menjamurnya pasar modern ditengah- tengah keberadaan pasar tradisional. Hal ini memunculkan persepsi di masyarakat yang beragam. Seperti yang kita ketahui bersama bahwa saat ini, banyak sekali perdebatan mengenai pasar tradisional melawan pasar modern. Segalanya bermula ketika banyak pedagang pasar tradisional yang gulung tikar yang diakibatkan oleh menjamurnya pasar-pasar modern. Banyak pendapat dan pandangan para ahli digulirkan. Peraturan presiden yang mengatur tentang hal ini pun juga telah dikeluarkan, yaitu Peraturan Presiden Nomor 112 Tahun 2007 tentang Penataan dan Pembinaan Pasar Tradisional, Pusat Perbelanjaan, serta Toko Modern.

Peraturan Daerah Provinsi Daerah Istimewa Yogyakarta Nomor 8 Tahun 2011 tentang Pasar Tradisional, Pusat Perbelanjaan, dan Toko Modern mengamanatkan bahwa jarak antar Pasar Tradisional dengan Toko Modern dan Pusat perbelanjaan adalah minimal 1000 meter atau $1 \mathrm{~km}$. Sementara itu, pada kenyataannya, hampir setiap 500 meter, kita akan sangat mudah menemukan pasar modern dan usaha waralaba modern. Hal ini menimbulkan masalah. Seiring dengan perkembangan waktu, adanya modernisasi dan meningkatnya kesejahteraan masyarakat, banyak masyarakat yang berbelanja di pasar modern dan mulai enggan berbelanja di pasar tradisional (kecuali untuk produk-produk yang tidak ada di supermarket).

Meskipun pasar modern terus berkembang, kehadiran Pasar Tradisional masih dibutuhkan oleh sebagian besar warga masyarakat. Para petani masih bergantung pada Pasar Tradisional untuk menjual hasil produksinya karena tidak semua hasil produksi mereka dapat menembus pasar modern. Mengingat pentingnya peran Pasar Tradisional bagi perekonomian dan kesejahteraan masyarakat, permasalahan-permasalahan seputar Pasar Tradisional harus segera diatasi. Peran aktif Pemerintah diharapkan dapat mengejar ketertinggalan dan meningkatkan daya saing Pasar Tradisional dalam kancah perdagangan yang semakin bebas sehingga nasib ribuan pelaku ekonomi yang terlibat di dalamnya dapat diselamatkan.

Pasar tradisional di Indonesia merupakan salah satu sektor yang memiliki posisi yang strategis dalam pembangunan perekonomian di Indonesia. 
Kestrategisan fungsi dan peran pasar tradisional dalam perekonomian daerah, juga ditunjukkan dari kontribusinya dalam Pendapatan Asli Daerah (PAD). Posisi yang sangat strategis dari eksistensi pasar tradisional, juga karena pasar tersebut masih merupakan wadah utama bagi penjualan produk-produk berskala ekonomi rakyat seperti petani, nelayan, pedagang barang kerajinan tangan, dan produk industri rumah tangga (industri rakyat).

Persaingan antara pasar modern dengan pasar tradisional semakin tak terkendali akhir-akhir ini di Kota Yogyakarta. Di Kota Yogyakarta terdapat 14 pasar modern yang terdiri dari Indomart, Alfamart, dan Circle $\mathrm{K}^{3}$, sedangkan menurut Peraturan Walikota Yogyakarta Nomor 57 Tahun 2016 Tentang Perubahan Ketiga Peraturan Walikota Nomor13 Tahun 2010 Tentang Petunjuk Pelaksanaan Peraturan Daerah Kota Yogyakarta Nomor2 Tahun 2009 Tentang Pasar, bahwa jumlah pasar tradisional yang ada di wilayah Kota Yogyakarta adalah 30 pasar tradisional.

Secara tidak langsung Pasar Tradisional menjadi pusat ekonomi terbuka untuk rakyat dan pusat budaya yang melibatkan aspek komunikasi literal, visual, verbal, dan non-verbal antarsesama. Pasar Tradisional tidak hanya berperan sebagai rumah ekonomi namun juga sebagai rumah budaya sehingga eksistensinya perlu dijaga. Hal-hal tersebut di atas membutuhkan peran aktif dari Pemerintah Daerah sebagai pengelola dan pemegang kebijakan. ${ }^{4}$

Pemerintah Kota Yogyakarta telah mengeluarkan kebijakan Peraturan Walikota Nomor 79 Tahun 2010 tentang Pembatasan Usaha Waralaba Minimarket di Kota Yogyakarta. Salah satu dasar dikeluarkanya peraturan walikota ini adalah Peraturan Presiden Nomor 112 Tahun 2007 tentang Pembinaan Penataan dan Pembinaan Pasar Tradisional, Pusat Perbelanjaan, dan Toko Modern. Kebijakan ini penting untuk melindungi keberadaan pasar tradisional. Poin penting Peraturan Walikota Nomor79 Tahun 2010 adalah bahwa keberadaan usaha waralaba minimarket hanya boleh berada di jalan-jalan yang sudah ditentukan oleh pemerintah kota. Jadi semua jalan yang diada di Kota Yogyakarta bisa ada usaha waralaba minimarket. Selain itu, perwali tersebut juga

${ }^{3}$ Tribun Jogja, 2015

${ }^{4}$ Aris Saputra dan Wiharto, "Pasar Tradisional: Rumah Budaya dan Rumah Ekonomi”, dalam M. Chatib Basri, dkk, (2012), Rumah Ekonomi dan Rumah Budaya: Membaca KebijakanPerdagangan Indonesia, Gramedia Pustaka Utama, Jakarta, hlm. 220. 
mengamanatkan bahwa di setiap kecematan yang ada di Kota Yogyakarta, hanya boleh berdiri usaha waralaba minimarket yang jumlahnya sudah ditentukan dalam perwali tersebut.

Beradasarkan uraian di atas, peneliti melihat penting untuk mengkaji efektivitas implementasi Peraturan Walikota Yogyakarta Nomor 79 Tahun 2010 tentang Pembatasan Usaha Waralaba Minimarket di Kota Yogyakarta dalam konteks hubungannya dengan keberadaan pasar tradisional.

\section{B. Telaan Konsep}

\section{Efektivitas}

Kata efektif berasal dari bahasa Inggris yaitu effective yang berarti berhasil atau sesuatu yang dilakukan berhasil dengan baik. Kamus ilmiah populer mendefinisikan efetivitas sebagai ketepatan penggunaan, hasil guna atau menunjang tujuan.

Efektivitas merupakan unsur pokok untuk mencapai tujuan atau sasaran yang telah ditentukan di dalam setiap organisasi, kegiatan ataupun program. Disebut efektif apabila tercapai tujuan ataupun sasaran seperti yang telah ditentukan. Efektivitas adalah pengukuran dalam arti tercapainya tujuan yang telah ditentukan sebelumnya. ${ }^{5}$

Upaya mengevaluasi jalannya suatu organisasi, dapat dilakukan melalui konsep efektivitas. Konsep ini adalah salah satu faktor untuk menentukan apakah perlu dilakukan perubahan secara signifikan terhadap bentuk dan manajemen organisasi atau tidak. Dalam hal ini efektivitas merupakan pencapaian tujuan organisasi melalui pemanfaatan sumber daya yang dimiliki secara efisien, ditinjau dari sisi masukan (input), proses, maupun keluaran (output). Dalam hal ini yang dimaksud sumber daya meliputi ketersediaan personil, sarana dan prasarana serta metode dan model yang digunakan. Suatu kegiatan dikatakan efisien apabila dikerjakan dengan benar dan sesuai dengan prosedur sedangkan dikatakan efektif bila kegiatan tersebut dilaksanakan dengan benar dan memberikan hasil yang bermanfaat.

${ }^{5}$ Handayaningrat, Suwarno. (1982). Administrasi Pemerintahan Dalam Pembangunan Nasional. Jakarta: PT. Gunung Agung 


\section{Kebijakan}

Kebijakan dalam Kamus Besar Bahasa Indonesia adalah rangkaian konsep dan asas yang menjadi garis besar dan dasar rencana dalam pelaksanaan suatu pekerjaan dalam mencapai tujuan atau sasaran. Secara etimologis, istilah kebijakan (policy) berasal dari bahsa Yunani, Sanksekerta dan Latin. Dalam bahasa Yunani dan kebijakan disebut dengan polis yang berarti " negara-kota" dan sansakerta disebut dengan pur yang berarti "kota" serta dalam bahasa Latin disebut dengan politia yang berarti negara. ${ }^{6}$

Beberapa ilmuwan menjelaskan berbagai macam mengenai kebijakan diantaranya, Carl Friedrich dalam Indiahono menyatakan bahwa kebijakan merupakan suatu arah tindakan yang diusulkan oleh seseorang, kelompok atau pemerintah dalam suatu lingkungan tertentu yang memberikan hambatanhambatan dan kesempatan-kesempatan terhadap kebijakan yang di usulkan untuk menggunakan dan mengatasi dalam rangka mencapai suatu tujuan, atau merealisasikan suatu sasaran atau suatu maksud tertentu. ${ }^{7}$.

Ia juga mengatakan bahwa didalam kebijakan terdapat suatu hal pokok yaitu adanya tujuan (goal), sasaran (objective) atau kehendak (purpose). Kebijakan yaitu : "Perilaku yang tetap dan berulang dalam hubungan dengan usaha yang ada didalam dan melalui pemerintah untuk memecahkan masalah umum. Definisi ini memberi makna bahwa kebijakan itu bersifat dinamis. Ini akan dibicarakan secara khusus dalam bagian lain, dalam hubungan dengan sifat dari kebijakan". 8

Kebijakan secara umum dibedakan menjadi 3 (tiga) tingkatan :?

a. Kebijakan umum, yaitu kebijakan yang menjadi pedoman atau petunjuk pelaksanaan baik yang bersifat positif ataupun yang bersifat negatif yang meliputi keseluruhan wilayah atau instansi yang bersangkutan.

b. Kebijakan pelaksanaan adalah kebijakan yang menjabarkan kebijakan umum. Untuk tingkat pusat, peraturan pemerintah tentang pelaksanaan suatu undang-undang.

${ }^{6}$ Dunn, William. (1994). Pengantar Analisis Kebijakan Publik. Yogyakarta. Gadjah Mada University Press

7Indiahono, Dwiyanto. (2009). Kebijakan Publik Berbasis Dynamic Policy. Analisys. Gava Media: Yogyakarta. ${ }^{9}$ Ibid

${ }^{8}$ Abidin, Said Zainal. (2004). Kebijakan Publik. Jakarta: Yayasan Pancur Siwah. 
c. Kebijakan teknis, yaitu kebijakan operasional yang berada dibawah kebijakan pelaksanaan

Berdasarkan penjelasan beberapa definisi terkait kebijakan di atas, maka dapat disimpulkan bahwa kebijakan merupakan upaya atau tindakan untuk mempengaruhi sistem pencapaian tujuan yang diinginkan. Upaya dan tindakan tersebut bersifat strategis yaitu berjangka panjang dan menyeluruh.

Konsep kebijakan memiliki beberapa implikasi, yakni: ${ }^{10}$

a. Titik perhatian dalam kebijakan publik berorientasi pada maksud atau tujuan dan bukan pada prilaku yang serampangan. Kebijakan publik secara luas dalam sistem politik modern bukan suatu yang terjadi begitu saja melainkan direncanakan oleh aktor yang terlibat dalam sistem politik.

b. Kebijakan merupakan arah atau pola tindakan yang dilakukan oleh pejabat-pejabat pemerintah dan bukan merupakan keputusan-keputusan tersendiri. Suatu kebijakan mencakup tidak hanya keputusan untuk menetapkan undang-undang mengenai suau hal tetapi juga keputusan keputusan besrta pelaksananya.

c. Kebijakan adalah apa yang sebenarnya dilakukan oleh pemerintah dalam mengatur perdagangan, mengendalikan inflasi, atau mempromosikan perumahan rakyat dan bukan apa yang di inginkan pemerintah.

d. Kebijakan publik mungkin dalam bentuknya bersifat positif atau negatif. Secara positif, kebijakan mungkin mencakup bentuk tindakan pemerintah yang jelas untuk mempengaruhi suatu masalah tertentu. Secara negatif, mungkin kebijakan mencakup suatu keputusan oleh pejabat-pejabat pemerintah, tatapi tidak untuk mengambil tindakan dan tidak untuk melakukan sesuatu mengenai suatu persoalan yang memerlukan keterlibatan pemerintah. Kebijakan publik memiliki paksaan yang secara potensial sah dilakukan. Hal ini berarti bahwa kebijakan publik menuntut ketaatan yang luas dari masyarakat. Sifat yang tarakhir inilah yang membedakan kebijakan publik dengan kebijakan lainya. 


\section{Peraturan Walikota Nomor 79 Tahun 2010}

Peraturan Walikota Yogyakarta Nomor79 Tahun 2010 adalah peraturan yang dikeluarkan oleh Walikota Yogyakarta untuk membatasi usaha waralaba minimarket yang ada di Kota Yogyakarta. Tujuannya adalah untuk memberdayakan Usaha Mikro, Kecil dan Menengah sertamencegah terjadinya penguasaan pasar dan pemusatan usaha oleh orang-perseorangan atau kelompok tertentu yang telah mempunyai jaringan usaha secara nasional yang merugikan Usaha Mikro, Kecil dan Menengah di wilayah Kota Yogyakarta, maka perlu adanya penyempurnaan terhadap ketentuan - ketentuan dalam peraturan sebelumnya, yaitu Peraturan Walikota Nomor 89 Tahun 2009. Poin kebijakan Peraturan Walikota Yogyakarta adalah ada 32 jalan di Kota Yogyakarta yang diperbolehkan untuk usaha waralaba minimarket dan dan hanya boleh ada 52 usaha waralaba minimarket yang tersebar di 14 kecamatan (rinciannya dapat dilihat pada lampiran Peraturan Walikota Yogyakarta Nomor 79 Tahun 2010)

\section{Pasar Tradisional}

Pasar Teradaisional adalah Pasar yang dibagun dan dikelola oleh Pemerintah Daerah,Swasta, Badan Usaha Milik Negara dan/ atau Badan Usaha Milik Daerah tersebut kerjasama dengan swasta berupa tempat usaha yang berbebtuk toko, kios, dan tenda yang dimiliki/ dikelola oleh pedagang kecil, menengah, koperasi dengan usahaskala kecil, modal kecil dan melalui proses jual beli barang dagangan dengan tawar-menawar.

Pasar tradisional adalah Tempat yang mempunyai unsur- unsur sosial, ekonomi, kebudayaan, politik dan lain- lain, tempat pembeli dan penjual (atau penukar tipe lain) saling bertemu untuk mengadakan tukar menukar. Bangunan biasanya terdiri dari kios- kios atau gerai,yang dibuka oleh penjual maupun pengelola pasar.Bahkan pasar merupakan ciri pokok dari jalinan tukar menukar yang menyatukan seluruh kegiatan ekonomi. Sehingga pasar merupakan penata penting dalam kegiatan ekomoni dan pemenuhan kebutuhan hidup masyarakat. $^{11}$ 
Sementara itu,dalam Peraturan Presiden Nomor 112 tahun 2007 secara umum pasar dapat diklasifikasikan ke dalam tiga kategori,yaitu:

a. Pasar Tradisional merupakan pasar dengan area jual beli yang dikembangkan dan dikelola secara resmi oleh pemerintah daerah dimana aktifitas tersebut hanya didukung oleh jumlah sarana serta tingkat kenyamanan yang relatif secukupnya. Termasuk dalam hal ini pasar regional,pasar kota, pasar wilayah dan pasarlingkungan.

b. Pasar moderen yaitu pasar dengan jual beli berbagai jenis barang yang dikelola secara terpadu dan pada umumnya menerapkan pola swalayan. Karakteristik yang terpenting dari pola pasar adalah adanya pengelolaaan moderen seperti manajemen,teknologi,serta promosi yang agresif,disamping tersedianya sarana belanja umum yang mewah,teratur, bersih dan nyaman. Pasar swalayan (supermarket), departemen store, pusat perbelanjaan seperti mall dan plaza termasuk dalamkategori pasar ini.

c. Pasar informal merupakan pasar dengan area jual beli yang menempati lokasi secara tidak legal, sehingga aktivitas perdagangan yang terjadi berlangsung mendalam suasana yang darurat dan seadanya. Pasar ini tidak memiliki sarana penunjung, peraturan, maupun kenyamaan berbelanja. Pasar ini biasanya terdapat di sekitar pasar formal,tidak keramaian di jalan dijalan raya atau diwilayah permukiman.

\section{Metode Penelitian}

Penelitian ini berjenis kualitatif dengan pendekatan deskriptif. penelitian kualitatif adalah metode penelitian yang berlandaskan pada filsafat postpositivisme, digunakan untuk meneliti pada kondisi objek yang alamiah, dimana peneliti adalah instrumen kunci, pengambilan sampel sumber data dilakukan secara purposive dan snowball, teknik pengumpulan data secara trianggulasi (gabungan), analisis data bersifat induktif/kualitatif, dan hasil penelitian kualitatif lebih menekankan makna daripada generalisasi. ${ }^{12}$

Teknik pengambilan data menggunakan teknik wawancara, observasi, dan dokumentasi. Subyek penelitian ini diambil berdasarkan kriteria yang dimiliki oleh peneliti dalam penentuan objek penelitian dan narasumber yang dianggap relevan

12Sugiyono, 2010, Metode Penelitian Pendidikan, Pendekatan Kualitatif, dan R\&D, Bandung: Alfabeta 
untuk dapat memberikan informasi mengenai efektivitas kebijakan pemerintah Kota Yogyakarta dalam melindungi pasar tradisional khususnya di delapan pasar yang menjadi objek penelitian adalah sebagai berikut:

1. Pasar Beringharjo

2. Pasar Ngasem

3. PASTY

4. Pasar Gading Mantrijeron

5. Pasar Telo Karangkajen

6. Pasar Giwangan

7. Pasar Kotagede

8. Pasar Klithikan Pakuncen

Jumlah informan pada penelitian ini adalah 40 informan yang tersebar di delapan pasar tersebut. Pengambilan informan secara purposive sampling yang terbagi dalam dua unit analisis, yaitu unit analisis pertama adalah para pedagang dari delapan pasar tersebut sebanyak 38 orang dan unit analisis kedua 2 (dua) orang, yaitu Kepala Dinas Perindustrian dan Perdagangan Kota Yogyakarta yang membawahi urusan pasar dan Staf Bidang Bimbingan Usaha dan Pengendalian, Pengawas Perdagangan.

Teknik analisa mengikuti pendekatan analisis deskriptif kualitatif dengan menggunakan model Miles and Huberman.yang meliputi: 1). Data reduction (reduksi data), yakni merangkum, memilih hal-hal pokok dan memfokuskan pada hal-hal penting dari sejumlah data lapangan telah diperoleh dan mencari polanya. 2). Data display (Penyajian data), yakni menampilkan data yang telah direduksi yang sifatnya sudah terorganisir dan mudah dipahami. Data dalam penelitian ini disajikan dalam bentuk deskripsi kata-kata dari kutipan wawancara dan gambar dengan maksud menjaga keorisinalitas data. 3). Conclution drawing/verification (kesimpulan), yakni akumulasi dari kesimpulan awal yang disertai dengan buktibukti valid dan konsisten (kredibel), sehingga kesimpulan dihasilkan dalam penelitian ini diarahkan untuk menjawab seluruh rumusan permasalahan.

Adapun deskripsi informan yang meruapakan pedagang pasar tradisioanal dapat dilihat pada tabel 1 di bawah ini. 


\section{Tabel 1}

Distribusi Informan Berdasarkan Pasar Tradisional

\begin{tabular}{|c|l|c|c|}
\hline Nomor & Pasar Tradisional & $\begin{array}{c}\text { Jumlah } \\
\text { Informan }\end{array}$ & $\begin{array}{c}\text { Persentase } \\
\mathbf{( \% )}\end{array}$ \\
\hline 1 & P. Beringharjo & 10 & 25 \\
\hline 2 & P. Ngasem & 5 & 12.5 \\
\hline 3 & PASTY & 5 & 12.5 \\
\hline 4 & P.Gading & 5 & 12.5 \\
\hline 5 & P. Telo & 5 & 12.5 \\
\hline 6 & P. Giwangan & 4 & 12.5 \\
\hline 7 & P. Kotagede & 2 & 7.5 \\
\hline 8 & P. Klitikan Pakuncen & 2 & 5 \\
\hline Jumlah & & 38 Orang & 100.0 \\
\hline
\end{tabular}

Berdasarkan tabel di atas dapat diketahui bahwa jumlah informan adalah 40 orang. 25\% informan berasal dari Pasar Beringharjo; Informan dari Pasar Ngasem, PASTY, Pasar Gading, Pasar Telo, Pasar Giwangan adalah sama-sama 12,5\%; Pasar Kotagede adalah 7,5\%; dan yang paling kecil adalah dari Pasar Klitikhan Pakuncen sebesar 5\%. Alasan menjadikan Pasar Beringharjo sebagai penyumbang informan terbanyak adalah karena Pasar Beringharjo merupakan pasar tradisional terbesar di wilayah Kota Yogyakarta.

\section{Pembahasan}

\section{Pengetahuan Informan Terhadap Peraturan Walikota}

Pengetahuan informan terhadap peraturan walikota adalah berkaitan dengan pengetahuan informan terhadap Peraturan Walikota Nomor 79 Tahun 2010 Tentang Pembatasan Usaha Waralaba Minimarket. Persentase tingkat pengetahuan informan dapat dilihat pada Tabel 2 berikut ini.

Tabel 2

Pengetahuan Informan Terhadap Perwali

\begin{tabular}{|c|c|c|c|}
\hline Nomor & Jawaban & $\begin{array}{c}\text { Jumlah } \\
\text { Informan }\end{array}$ & $\begin{array}{c}\text { Persentase } \\
\mathbf{( \% )}\end{array}$ \\
\hline 1 & Ya & 12 & 30.0 \\
\hline 2 & Tidak & 28 & 70.0 \\
\hline Jumlah & & 40 (Orang) & 100.0 \\
\hline
\end{tabular}

Berdasarkan tabel di atas dapat diketahui bahwa persentase informan yang mengetahui kebijakan Peraturan Walikota Nomor 79 Tahun 2010 adalah sebesar 
30\%. Hal ini jauh lebih kecil dari persentase informan yang tidak mengetahui kebijakan peraturan walikota (perwali) tersebut. Hal ini dapat sebabkan oleh beberapa hal, antara lain: kurangnya sosialisasi dari Pemerintah Kota Yogyakarta terkait adanya kebijakan tersebut atau minimnya kesadaran masyarakat untuk memahami kebijakan yang dikeluarkan oleh pemerintah kota. Hal ini sesuai dengan hasil wawancara dengan salah seorang pedagang di Pasar Beringharjo yang dapat dilihat pada kutipan wawancara di bawah ini:

"Sebenarnya kurangnya pengetabuan masyarakat dalam hal ini pedagang pasar terkait peraturan itu disebabkan oleh kurangnya sosialiasi yang dilakukan oleh pemerintah kota."

Hal tersebut, terkait penyebab lain, diuangkapkan salah seorang pedagang di Pasar Ngasem, yang dapat dilihat pada kutipan wawancara di bawa ini:

"Sebenarnya masyarakat dan pada intinya pedagang di pasar tradisional menilai pemerintah sudah pro terbadap rakyat kecil. Cuman halnya, masyarakat pada umumnya kurang memiliki kesadaran untuk mau tahu terbadap apa yang dikeluarkan pemerintah. Kadang-kadang, seolah-olah pemerintah dianggap tidak pernah mendukung rakyat."

\section{Dukungan Informan Terhadap Peraturan Walikota}

Dukungan informan terhadap peraturan walikota berkaitan dengan respon baik masyarakat terhadap kebijakan Peraturan Walikota Nomor79 Tahun 2010 Tentang Pembatasan Usaha Waralaba Minimarket di Kota Yogyakarta. Dukungan informan atau masyarakat terhadap kebijakan pemerintah kota sangat dibutuhkan karena dukungan tersebut dapat menjadi salah satu kunci keberhasilan penerapan kebijakan peraturan walikota tersebut untuk mewujudkan kesejahteraan rakyat.

Dukungan informan terhadap kebijakan Peraturan Walikota Nomor79 Tahun 2010 dapat dilihat pada Tabel 3.5 berikut ini.

Tabel 3

Dukungan Informan Terhadap Perwali

\begin{tabular}{|c|c|c|c|}
\hline Nomor & Jawaban & $\begin{array}{c}\text { Jumlah } \\
\text { Informan }\end{array}$ & $\begin{array}{c}\text { Persentase } \\
\mathbf{( \% )}\end{array}$ \\
\hline 1 & Ya & 39 & 97.5 \\
\hline 2 & Tidak & 1 & 2.5 \\
\hline Jumlah & & 40 (Orang) & 100.0 \\
\hline
\end{tabular}

Berdasarkan tabel di atas, dapat diketahui bahwa 97,5\% informan memberikan respon mendukung terhadap kebijakan Peraturan Walikota Nomor79 
Tahun 2010 Tentang Pembatasan Usaha Waralaba Minimarket di Kota Yogyakarta. Hal ini disebabkan oleh karena masyarakat sangat menginginkan adanya keseimbangan berdasarkan prinsip keadilan dalam berusaha dan berdagang. Masyarakat menganggap bahwa kehadiran kebijakan peraturan walikota tersebut sangat pro terhadap masyarakat terutama rakyat kecil yang salah satu mata pencahariannya adalah sebagai pedagang yang berdagang di pasar tradisional atau yang dapat dikategorikan usaha kecil. Hal ini sesuai dengan wawancara yang dilakukan dengan salah satu pedangan di Pasar Satwa dan Tanaman hias Yogyakarta (PASTY) yang bernama Ahmad, sebagai berikut:

"Kami sebenarnya sangat mendukung setiap apa yang baik dan pro rakyat kecil yang dikeluarkan oleb pemerintah. Ini berarti pemerintah sangat menghargai prinsip keseimbangan berdasarkan prinsip keadilan yang mendukung usaha kecil. Intinya, kami sangat mendukung."

Sedangkan di lain pihak, seorang pedagang di Pasar Telo menguraikan alasan mengapa ia mendukung kebijakan peraturan walikota yang membatasi usaha waralaba minimarket, seperti yang pada kutipan wawncara di bawah ini:

“.... justru bagus mbak, Kami merasa pemerintah kota memperhatikan kami. Kami ini kan pedagan to mbak. Mata pencaharian kami dari sini. Salut untuk pemkot.”

Sedangkan informan yang tidak mendukung kebijakan Peraturan Walikota Nomor79 Tahun 2010 adalah hanya 2,5\%. Hal ini dapat disebabkan oleh ketidakpahaman masyarakat atau informan yang bersangkutan terhadap kebijakan tersebut. Selain itu, masyarakat yang tidak mendukung kebijakan tersebut karena pemerintah tidak serius menerapkannya. Hal ini sesuai dengan hasil wawancara dengan salah satu pedagang di Pasar Kotagede yang tidak mau disebutkan identitasnya, sebagai berikut:

"Saya tidak mendukung mas, wong sekarang Indomart dan Alfamart berdampingkan kok. Para pelanggan lari ke mereka semua. Pemerintah tidak serius. Sukanya bikin aturan tapi dilanggar sendiri.”

\section{Keefektivitasan Peraturan Walikota Nomor 79 Tahun 2010 Dalam} Melindungi Keberadaan Pasar Tradisional

Keefetivitasan kebijakan Peraturan Walikota Nomor79 Tahun 2010 dalam memberikan perlindungan terhadap keberadaan pasar tradisional adalah 
berkaitan dengan sumbangsi atau kontrbusi kebijakan tersebut dalam memberikan perlindungan terhadap keberadaan pasar tradisional yang berada di wilayah Kota Yogyakarta yang mana keberadaannya sedang bersaing dengan munculnya pasar modern atau usaha waralaba. Peraturan Walikota Nomor 79 Tahun 2010 dikeluarkan untuk membatasi usaha waralaba minimarket. Usaha Waralaba adalah hak khusus yang dimiliki oleh orang perseorangan atau badan usaha yang sudah mempunyai jaringan secara nasional terhadap sistem bisnis dengan ciri khas usaha dalam rangka memasarkan barang dan/atau jasa yang telah terbukti berhasil dan dapat dimanfaatkan dan/atau digunakan oleh pihak lain berdasarkan perjanjian waralaba. Sedangkan, Minimarket adalah toko modern dengan batasan luas lantai penjualan kurang dari $400 \mathrm{~m} 2$ (empat ratus meter persegi).

Ruang lingkup peraturan walikota ini adalah usaha waralaba yang berbentuk minimarket dengan sistem pelayanan mandiri, menjual secara eceran berbagai jenis barang kebutuhan sehari-hari dan anak cabang perusahaan yang menjual secara eceran berbagai jenis barang kebutuhan sehari-hari dengan menggunakan nama atau merk yang sama yang merupakan kerjasama langsung sebagai jejaring usaha dengan perusahaan besar yang berskala nasional.

Keefektivitasan kebijakan ini berhubungan dengan pengaruh dan perlindungan yang dikontribusikan kepada keberadaan pasar tradisional oleh adanya Peraturan Walikota Yogyakarta Nomor79 Tahun 2010. Namun demikian, ternyata peraturan ini justru tidak ada hubungannya dengan keberadaan pasar tradisional. Hal ini dapat dilihat pada kutipan wawancara dengan staf Dinas Perindustrian dan Perdagangan Kota Yogyakarta, di bawah ini:

"Jadi antara dikeluarkan kebijakan peraturan walikota ini dengan keberadaan pasar tradisional, bubungannya dapat dikatakan kurang berpengaru. Yang sebenarnya berpengaruh adalah toko kelontong. Sebabnya adalah karena pasar tradisional sudah memiliki segmen tersendiri. Jadi, adanya minimarket itu tidak berpengarub. Sebenarnya ada pengarubnya, tapi sangat sedikit persentasenya atau pengarubnya."

Berdasarkan hasil wawancara di atas, dapat diketahui bahwa adanya kebijakan Peraturan Walikota Yogyakarta Nomor79 Tahun 2010 sangat kurang pengaruhnya terhadap keberadaan pasar tradisional. Hal ini disebabkan karena 
pasar tradisional mempunyai segmen tersendiri. Segmen yang dimaksud pada konteks ini adalah pasar tradisional memiliki tempatnya sendiri yang telah dijamin dan dilindungi oleh pemerintah. Dengan demikian, keberadaan minimarket atau usaha waralaba dapat dikatakan tidak tidak mengancam keberadaan pasar trasdisional. Segmentasi juga berkaitan dengan pembeli atau konsumen yang berkunjung ke pasar tradisional tidak dipengaruhi oleh keberadaan minimarket dalam hal preferensi membeli barang-barang yang dijual di pasar tradisional.

Toko kelontong adalah justru usaha yang berhubungan langsung dengan adanya kebijakan peraturan walikota tersebut. Toko kelontong adalah usaha perorangan dalam skala kecil yang kepemilikannya secara perorangan. pada kenyataannya, toko kelontong sebenarnya terancam dengan kehadiran usaha waralaba minimarket yang lokasinya juga sangat berdekatan. Kehipan modern yang menentukan preferensi daya beli masyarakat yang lebih suka hal-hal yang bersifat kepraktisan dan variasi barang yang dijual dapat mengancam keberadaan pasar kelontong. Tidak adanya batasan jam untuk berjualan pada toko kelontong justru membuatnya tidak kuat bersaing dengan usaha waralaba minimarket. Lain halnya dengan pasar tradisional yang selain memiliki segmentasi tersendiri bagi masyarakat untuk membeli kebutuhan yang lebih bervariasi dan harga yang kompetitif, juga memiliki batasan waktu untuk berjualan yang diberlakukan kepada pedagang. Namun demikian, penelitian ini tidak membahas toko kelontong.

Pada sisi lain, sekalipun kebijakan yang membatasi usaha waralaba minimarket tidak ada berpengaruh terhadap keberadaan pasar tradisional menurut pihak Dinas Perindustrian dan Perdagangan Kota Yogyakarta, informan yang mewakili masyarakat dan pedagang pasar tradisional pada penelitian ini justru memberikan respon terkait keefektivitasan kebijakan Peraturan Walikota Nomor79 Tahun 2010 yang sedikit berbeda yang dapat dilihat pada tabel berikut ini. 
Tabel 4

Respon Informan Terhadap Keefektivitasan Perwali

\begin{tabular}{|c|c|c|c|}
\hline Nomor & Jawaban & $\begin{array}{c}\text { Jumlah } \\
\text { Informan }\end{array}$ & $\begin{array}{c}\text { Persentase } \\
\mathbf{( \% )}\end{array}$ \\
\hline 1 & Ya & 35 & 87.5 \\
\hline 2 & Tidak & 5 & 12.5 \\
\hline Jumlah & & 40 (Orang) & 100.0 \\
\hline
\end{tabular}

Berdasarkan Tabel 4 dapat dilihat bahwa persentase informan yang mengatakan bahwa kebijakan peraturan walikota yang membatasi usaha waralaba minimarket efektif dalam memberikan perlindungan kepada keberadaan pasar tradisional adalah sebesar 87,5\%. Hal ini dapat dipahami karena informan yang semuanya berprofesi sebagai pedagang hanya dapat memahami bahwa kebijakan tersebut merupakan kebijakan yang pro terhadap pedagang kecil. Jadi, apapun yang dilakukan pemerintahnya, mereka dengan senang hati akan mendukung, asalkan kebijakan tersebut mendukung prinsip keadilan dalam berdagang. Hal tersebut juga berbeda dari hasil wawancara dengan salah satu staf Dinas Perindustrian dan Perdagangan Kota Yogyakarta yang memiliki jenjang pendidikan yang lebih tinggi dan lebih memahami arah dan pengaruh kebijakan. Namun, setidaknya para informan tersebut memiliki kesadaran untuk berusaha memahami dan mendukung apa setiap kebijakan yang dikeluarkan oleh Pemerintah Kota Yogyakarta.

Informan yang mengatakan kebijakan tersebut tidak efektif adalah 12,5\%. Hal ini dapat disebabkan oleh kurangnya pemahaman informan terhadap substansi kebijakan peraturan walikota tersebut. Selain itu, argumentasi informan didasari atas pengamatannya secara langsung terhadap implementasi kebijakan tersebut yang kurang memberikan perlindungan terhadap usaha kecil, termasuk yang berjualan di pasar tradisional. Namun demikian, kebijakan peraturan Walikota Yogyakarta yang membatasi usaha waralaba minimarket dapat diambil kesimpulan efektif untuk memberikan perlindungan terhadap keberadaan pasar tradisional.

\section{Penerapan Peraturan Walikota}

Respon masyarakat tehadap Peraturan kebijakan Peraturan Walikota Yogyakarta Nomor79 Tahun 2010 terkait penerapannnya dapat dilihat pada tabel berikut ini. 
Tabel 5

Penerapan Perwali

\begin{tabular}{|c|l|c|c|}
\hline Nomor & Penerapan Perwali & $\begin{array}{c}\text { Jumlah } \\
\text { Informan }\end{array}$ & $\begin{array}{c}\text { Persentase } \\
\mathbf{( \% )}\end{array}$ \\
\hline 1 & Di Seluruh Kota Yogya & 39 & 97.5 \\
\hline 2 & Di lokasi jualan & 1 & 2.5 \\
\hline 3 & Tempat lain & 0 & 0.0 \\
\hline Jumlah & 40 & 100.0 \\
\hline
\end{tabular}

Berdasarkan Tabel 5 di atas dapat dilihat bahwa informan yang menginginkan kebijakan Peraturan Walikota Nomor79 Tahun 2010 diterapkan di di seluruh Kota Yogyakarta adalah 97,5\%. Sedangkan, 2.5\% informan menginginkan kebijakan peraturan walikota tersebut diterapkan di lokasi ia berjualan saja. Tidak ada informan yang memilih untuk diterapkan di tempat lain.

Kutipan wawancara dengan salah satu pedagang di Pasar Gading yang menginginkan kebijkan tersebut diterapkan di seluruh wilayah Kota Yogyakarta adalah sebagai berikut:"Sebaiknya dan lebih bagusnya diterapkan di seluruh wilayah Kota Yogyaakarta. Biar lebih merata."

\section{Perevisian Peraturan Walikota}

Pendapat informan terkait perevisian peraturan walikota yang membatasi usaha waralaba minimarket di Kota Yogyakarta dapat dilihat pada Tabel 3.8 berikut ini.

\section{Tabel 7}

Respon Informan Terkait Revisi Perwali

\begin{tabular}{|c|c|c|c|}
\hline Nomor & Jawaban & $\begin{array}{c}\text { Jumlah } \\
\text { Informan }\end{array}$ & $\begin{array}{c}\text { Persentase } \\
\mathbf{( \% )}\end{array}$ \\
\hline 1 & Ya & 19 & 47.5 \\
\hline 2 & Tidak & 21 & 52.5 \\
\hline Jumlah & & 40 (Orang) & 100.0 \\
\hline
\end{tabular}

Berdasakan tabel di atas, 47,5\% informan mengharapkan kebijakan peraturan walikota yang membatasi usaha waralaba minimarket direvisi. Hal ini disebabkan oleh karena kebijakan tersebut tidak terlalu melindungi usaha kecil termasuk pedagang di pasar tradisional. Sedangkan 52,5\% informan berpendapat bahwa kebijakan tersebut tidak perlu direvisi atau belum saatnya direvisi. Mereka berpendapat bahwa kebijakan tersebut dapat dikatakan tidak berpengaruh 
terhadap keberadaan pasa tradisional. Terkait dengan hal ini, Staf Dinas Perindustrian dan Perdagangan Kota Yogyakarta menguraikan alasan mengapa kebijakan tersebut tidak perlu direvisi. Berikut kutipannya:

'Dalam konteks merevisi peraturan walikota ini diperlukan kehati-hatian. Jangan sampai kebijakan yang dikeluarkan dan berikut revisi-revisinya bertolak belakang dengan peraturan yang tingkatannya lebih tinggi, seperti peraturan menteri terkait. Prinsip kehati-hatian itu juga merupakan sikap yang tepat yang diambil oleh pemerintah kota untuk menindaklanjuti dan mendukung kebijakan pemerintah pusat yang mendorong investasi di daerah.

Berdasarkan hasil wawancara di atas dapat diketahui bahwa dalam mengeluarkan kebijakan dan peraturan, pemerintah kota mengutamakan prinsip kehati-hatian. Hal tersebut perlu dipertimbangkan agar setiap kebijakan yang dibuat tidak bertentangan dengan kebijakan yang lebih tinggi, seperti peraturan menteri. Hal ini juga berlaku terhadap kebijakan peraturan walikota yang membatasi usaha waralaba minimarket. Pertimbangan kehati-hatian itulah yang mendasari peraturan walikota tersebut belum perlu direvisi. Pemerintah Kota Yogyakarta juga harus mendukung kebijakan investasi yang dikeluarkan oleh pemerintah pusat. Setiap kebijakan yang dikeluarkan oleh pemerintah daerah tidak boleh bertentangan kebijakan pemerintah pusat.

\section{E. Penutup}

Berdasarkan deskripsi data dan pembahasan, maka penelitian yang bertujuan untuk mengetahui keefektivitasan kebijakan Peraturan Walikota Nomor79 Tahun 2010 Tentang Pembatasan Usaha Waralaba Minimarket dapat ditarik kesimpulan sebagai berikut:

Kebijakan Peraturan Walikota Yogyakarta Nomor79 Tahun 2010 tentang pembatasan usaha waralaba minimarket belum diketahui oleh seluruh pedagang yang berjualan di pasar tradisional yang berada di wilayah Kota Yogyakarta.Kebijakan Peraturan Walikota Yogyakarta Nomor79 Tahun 2010 dinilai efektif dalam memberikan perlindungan terhadap keberadaan pasar tradsional di wilayah Kota Yogyakarta.Kebijakan Peraturan Walikota Yogyakarta Nomor79 Tahun 2010 didukung pelaksanannya oleh sebagian pedagang di pasar Tradisional di wilayah Kota Yogyakarta.

Pemerintah Kota Yogyakarta perlu melaksanakan sosialisasi yang berkelanjutan untuk memberikan pengetahuan kepada pedagang pasar tradisional 
terhadap kebijakan peraturan walikota.Peraturan walikota yang membatasi usaha waralaba minimarket di Kota Yogyakarta harus benar-benar ditegakkan untuk melindungan keberadaan pasar tradisional. Kebijakan Peraturan Walikota Yogyakarta Nomor79 Tahun 2010 harus diterapkan di seluruh wilayah Kota Yogyakarta agar melindungi pedagang dengan usaha kecil, tetapi tidak perlu direvisi saat ini.

\section{DAFTAR PUSTAKA}

Abidin, Said Zainal, (2004), Kebijakan Publik. Jakarta: Yayasan Pancur Siwah.

Dunn, William, (1994). Pengantar Analisis Kebijakan Publik, Yogyakarta. Gadjah Mada University Press

Handayaningrat, Suwarno, (1982,. Administrasi Pemerintahan Dalam Pembangunan Nasional, Jakarta: PT. Gunung Agung

Indiahono, Dwiyanto, (2009), Kebijakan Publik Berbasis Dynamic Policy. Analisys. Gava Media: Yogyakarta

Sugiyono, 2010, Metode Penelitian Pendidikan, Pendekatan Kualitatif, dan R\&D, Bandung: Alfabeta

Winarno, B, (2002),Kebijakan Publik, teori, proses dan Studi kasus. Yogyakarta : PT. Buku Seru.

Peraturan Walikota Nomor 89 Tahun 2009

Peraturan Presiden Nomor 112 Tahun 2007 tentang Penataan dan Pembinaan Pasar Tradisional, Pusat Perbelanjaan, serta Toko Modern.

Peraturan Daerah Provinsi Daerah Istimewa Yogyakarta Nomor 8 Tahun 2011 tentang Pasar Tradisional, Pusat Perbelanjaan, dan Toko Modern

Peraturan Walikota Yogyakarta Nomor 57 Tahun 2016 Tentang Perubahan Ketiga Peraturan Walikota Nomor13 Tahun 2010 Tentang Petunjuk Pelaksanaan Peraturan Daerah Kota Yogyakarta Nomor2 Tahun 2009 Tentang Pasar

Peraturan Walikota Nomor 79 Tahun 2010 tentang Pembatasan Usaha Waralaba Minimarket di Kota Yogyakarta. 